\title{
RESPON POC HERBAFARM DAN KOMPOS TANDAN KOSONG KELAPA SAWIT TERHADAP DUA JENIS MENTIMUN MERCY (Cucumis sativus L.)
}

\author{
RESPONSES POC HERBAFARM AND OIL PALM EMPTY FRUIT \\ BUNCHES COMPOST FOR THE TWO TYPES OF \\ CUCUMBER MERCY (Cucumis sativus L.)
}

\author{
F. Fathurrahman*, Sri Mulyani, Jumaidi BZ Saputra \\ JProgram Studi Agroteknologi, Fakultas Pertanian, Universitas Islam Riau \\ Jl. Kaharuddin Nasution No. 113 P. Marpoyan Pekanbaru, Riau 28284 \\ *Email:fathur@agr.uir.ac.id
}

\begin{abstract}
The opportunity to development the cultivation of cucumber quite well in Indonesia. Efforts to increase production engineering improvements in the addition of nutrients. This research was conducted at UIR Agro Tourism Unit of Univeresitas Islam Riau Pekanbaru, from March to May 2019. New varieties such as cucumber (Cucumis sativus L.) mutation has a special attraction for example, there was an interesting morphological characters. The study aims to look the responses POC herbafarm and oil palm empty fruit bunches (OPEFB) compost for the two types of cucumber mercy (Cucumis sativus L.). Using a completely randomized design (CRD) factorial with two factors and three replications. First: POC Herbafarm consists of 4 levels i.e. without herbafarm, POC Herbafarm with 5, 10 and $15 \mathrm{ml} /$ lof water. Factor two: OPEFB compost consists of 4 levels i.e. without OPEFB compost, OPEFB compost with 15, 20 and 25 tonnes / ha. The observation of a cucumber plant height at the mercy F1 in combinations treatment proved H2T2A1 POC herbafarm concentration and dose of OPEFB best compost on cucumbers mercy $F 1$. In addition, the observation date of flowering was the best treatment along the combinations of $15 \mathrm{ml}$ / l herbafarm and 15 ton / ha OPEFB compost. The highest number of fruits obtained from $15 \mathrm{ml} / \mathrm{l}$ herbafarm and 25 ton / ha OPEFB compost treatment for mercy mutants. The Treatment $15 \mathrm{ml} / \mathrm{l}$ herbafarm and 25 ton / ha OPEFB compos, next $10 \mathrm{ml} / \mathrm{l}$ herbafarm and 20 ton / ha OPEFB compost prove produce the highest fruit weight and length for the cucumber mercy F1. The observation of brix, POC herbafarm concentration and dose of highest OPEFB compost to influence for both types.
\end{abstract}

Keywords: Cucumber mercy F1, Cucumber mercy mutants, POC Herbafarm, OPEFB Compost

\begin{abstract}
ABSTRAK
Peluang pengembangan budidaya sayuran mentimun cukup baik di Indonesia. Untuk meningkatkan produksinya dilakukan upaya perbaikan dalam teknik penambahan unsur hara. Penelitian ini telah dilaksanakan di UPT Agrowisata Universitas Islam Riau Pekanbaru, Riau pada bulan Maret sampai Mei 2019. Varietas baru mentimun (Cucumis sativus L.) hasil mutasi memiliki daya tarik tersendiri misalnya terdapat karakter morfologi yang menarik.
\end{abstract}


Penelitian bertujuan melihat respon POC herbafarm dan kompos tandan kosong kelapa sawit terhadap dua jenis mentimun mercy (Cucumis sativus L.). Menggunakan rancangan acak lengkap (RAL) secara faktorial terdiri dari dua faktor dan tiga ulangan. Pertama: POC Herbafarm 4 taraf yaitu tanpa herbafarm, 5, 10 dan 15 ml/l air. Faktor Kedua: pupuk kompos TKKS 4 taraf yaitu tanpa kompos TKKS, kompos TKKS 15, 20 dan 25 ton/ha. Hasil pengamatan tinggi tanaman pada mentimun mercy F1 pada perlakuan kombinasi $10 \mathrm{ml} / \mathrm{l}$ herbafarm dan 20 ton/ha kompos TKKS membuktikan konsentrasi tersebut merupakan yang terbaik. Selain itu juga pada pengamatan umur berbunga merupakan perlakuan yang terbaik bersama kombinasi $15 \mathrm{ml} / \mathrm{l}$ herbafarm dan 15 ton/ha kompos TKKS. Jumlah buah tertinggi diperoleh dari perlakuan $15 \mathrm{ml} / \mathrm{l}$ herbafarm dan 25 ton/ha kompos TKKS untuk mercy mutan. Perlakuan $15 \mathrm{ml} / 1$ herbafarm dan 25 ton/ha kompos TKKS mentimun mercy F1 dan $10 \mathrm{ml} / \mathrm{l}$ herbafarm dan 20 ton/ha kompos TKKS membuktikan menghasilkan berat dan panjang buah tertinggi pada mentimun mercy F1. Hasil pengamatan brix, konsentrasi POC herbafarm dan dosis kompos TKKS tertinggi mempengaruhi kedua jenis mentimun.

Kata kunci: Mentimun mercy F1, Mentimun mercy mutan, POC Herbafarm, Kompos TKKS.

\section{PENDAHULUAN}

Produksi mentimun (Cucumis sativus L.) di Riau khususnya mengalami fluktuasi yang dipengaruhi oleh beberapa hal diantaranya penggunaan teknologi pemupukan yang belum memadai, jenis bibit yang digunakan dan persoalan harga yang sering tidak stabil. Berdasarkan data Badan Pusat Statistik Provinsi Riau (2017), tahun 2013 luas areal panen mentimun 49.296 ha dengan produksi 491.636 ton. Tahun 2014 luas areal panen mentimun menurun menjadi 47.233 ha dengan produksi juga menurun menjadi 471.640 ton. Tahun 2015 luas areal panen mentimun menurun lagi menjadi 1.675 ha dan produksi juga menurun menjadi 14.175 ton. Dari data tersebut dapat dijelaskan kecenderungan penurunan luas lahan dan produksi mentimun setiap tahun terus terjadi.

Pupuk organik cair (POC) Herbafarm merupakan pupuk dari obat-obatan yang berfungsi sebagai dekomposer, penyedia nutrisi alam, meningkatkan kesuburan tanah melalui perbaikan terhadap kondisi biologis, kimia dan fisik tanah serta meningkatkan imunitas dan adaptasi tanaman terhadap faktor lingkungan yang kurang baik bagi pertumbuhannya (Suriadikarta dkk, 2013). Pupuk ini dapat merangsang pertumbuhan tanaman dan meningkatkan aktivitas mikrobiologi tanah. Peningkatan kesuburan tanah akan meningkatkan pertumbuhan dan produksi mentimun.

Upaya peningkatan kesuburan tanah yang lain dapat dilakukan dengan pupuk organik kompos Tandan Kosong Kelapa Sawit (TKKS). Kompos TKKS adalah limbah organik hasil olahan pabrik kelapa sawit digunakan sebagai pupuk organik. Kandungan nutrisinya adalah 1,5\% Nitrogen, $0,5 \%$ Posfor, 7,30\% Kalium dan 0,9\% Magnesium (Sarwono, 2008), sehingga berpeluang dan potensi sebagai sumber nutrisi bagi tanaman (Pusat Penelitian Kelapa Sawit, 2000).

Poliploidi dengan kolkisin merupakan salah satu teknik peningkatan varian genetik dan sekaligus digunakan sebagai salah satu metode pemuliaan 
tanaman (Dinarti dkk, 2006). Penelitian penggunaan benih mentimun varietas mercy F1 dan mercy mutan diharapkan memberikan informasi morfologi yang penting apakah akan terjadi peningkatan atau penurunan pertumbuhan mentimun. Berdasarkan hasil penelitian sebelumnya perlakuan kolkisin dapat memberikan pengaruh nyata pada pertumbuhan dan hasil tanaman baik terjadi peningkatan pertumbuhan dan produksi tanaman maupun sebaliknya. Hasil ini dapat dijadikanacuan awal kolkisin efektifmempengaruhi mutasi atau merubah ploidi ( Evi dkk, 2016).

Berdasarkan latar belakang di atas, perlu dilakukan penelitian mengenai respon kedua jenis pupuk organik terhadap pertumbuahan dan produksi mentimun dari dua varietas yang berbeda. Penelitian ini bertujuan untuk mengetahui respon POC herbafarm dan kompos tandan kosong kelapa sawit terhadap dua jenis mentimun mercy (Cucumis sativus L.).

\section{BAHAN DAN METODE}

Penelitian ini telah dilaksanakan pada bulan Maret sampai Mei 2019 di UPT Agrowisata Universitas Islam Riau Pekanbaru, Riau. Bahan-bahan yang digunakan dalam penelitian ini benih mentimun mercy F1 dan mercy mutan, POC Herbafarm dan kompos TKKS. Sedangkan alat yang digunakan adalah terdiri dari alat pengolahan tanah (cangkul dan garu), ember, sprayer, timbangan digital, meteran, refractometer brix, timbangan biasa, jangka sorong, alat-alat labor dan alat tulis. Penelitian ini dilaksanakan secara eksperimen menggunakan Rancangan Acak Lengkap (RAL) terdiri dari dua faktor dan tiga ulangan. Faktor pertama yaitu konsentrasi POC herbafarm terdiri dari 4 taraf. H0 : tanpa herbafarm, H1 : konsentrasi herbafarm 5, 10 dan 15 cc/l air. Faktor kedua pupuk kompos TKKS terdiri dari 4 taraf. T0: tanpa kompos TKKS, T1: kompos TKKS 15, 20 dan 25 ton/ha. Terdapat 16 kombinasi dengan tiga ulangan jumlah keseluruhan adalah 48 plot, setiap unit percobaan diambil tiga tanaman sebagai sampel.

Pelaksanaan penelitian terdiri dari persiapan lahan, pengolahan tanah dan pemberian perlakuan yang terdiri dari POC herbafarm dengan cara menyiram larutan herbafarm ke tanaman secara merata satu minggu setelah tanam menggunakan gembor. Pemberian kompos TKKS ditaburkan di atas permukaan tanah pada ukuran plot $100 \times 100 \mathrm{~cm}$ sesuai dosis perlakuan, kompos dicampur rata dengan tanah pada saat pengolahan tanah kedua. Penanaman benih cara ditugal pada lubang tanam sedalam $2 \mathrm{~cm}$ dengan jarak tanam $50 \mathrm{~cm}$ x $50 \mathrm{~cm}$. Kemudian dilakukan pemeliharaan tanaman yang terdiri penyiraman, penyulaman, penyiangan, pembumbunan dan pengendalian hama serta penyakit.

Pengendalian serangan hama dilakukan dengan menyemprotkan insektisida alami diberikan pada saat tingkat serangan (gejala) sudah terlihat pada tanaman. Pengendalian hama dan penyakit hanya dilakukan sekali pada saat tanaman berumur 35 hari setelah tanam (hst).

Parameter pengamatan yang dilakukan antara lain umur berbunga, jumlah buah per tanaman (buah), jumlah buah per plot (buah), panjang buah terpanjang (cm), berat buah per tanaman, dan pengujian tingkat kemanisan (brix). Data hasil pengamatan dianalisis 
secara statistik dan kemudian disajikan dalam bentuk tabel.

Rancangan penelitian yang digunakan adalah rancangan split plot. Data pengamatan dianalisis secara statistika menggunakan Analisys of Variance (ANOVA) dengan uji $\mathrm{F}$ pada tarafalfa 5\% menggunakan perangkat lunak SAS 9.1.3. Jika perlakuan berpengaruh nyata dilanjutkan dengan uji lanjutan Duncan Multiple Range Test (DMRT) pada taraf alfa 5\%. Model linier sebagai berikut:

$$
\mathrm{Ypkn}=\mu+\mathrm{Pp}+\mathrm{Kk}+\sum(\mathrm{pkn})
$$

Keterangan :

Ypkn = Variabel hasil pengamatan dari POC Herbafarm taraf ke -p dan Kompos TKKS taraf ke -k

$\mu \quad=$ Efek pengaruh rerata nilai tengah

$\mathrm{Pp}=$ Pengaruh faktor $\mathrm{P}$ pada taraf $\mathrm{ke}-\mathrm{p}$

$\mathrm{Kk} \quad=$ Pengaruh faktor $\mathrm{K}$ pada taraf $\mathrm{ke}-\mathrm{k}$

$\mathrm{PpKk}=$ Pengaruh interaksi antara faktor P pada taraf ke - p dan faktor K pada taraf ke - $\mathrm{k}$

$\sum(\mathrm{pkn})=$ Efek error dari factor $\mathrm{P}$ pada taraf ke $-\mathrm{p}$ dan faktor K pada taraf ke - $\mathrm{k}$ serta ulangan sampai ke - $\mathrm{n}$

$\mathrm{P} \quad=0,1,2,3$ (POC Herbaram )

$\mathrm{K}=0,1,2,3($ Kompos TKKS)

$\mathrm{n} \quad=1,2,3$ (Ulangan)

\section{HASIL DAN PEMBAHASAN}

\section{Tinggi tanaman (cm)}

Interaksi perlakuan POC Herbafarm dan kompos TKKS pada kedua jenis tanaman mentimun mercy F1 dan mercy mutan menunjukkan terdapat perbedaan nyata pada parameter pengamatan tinggi tanaman dapat dilihat pada Tabel 4.1. Perlakuan terbaik adalah interaksi POC herbafarm $(10 \mathrm{cc} / \mathrm{l})$ dan kompos TKKS (20 ton/ha) pada mentimun mercy F1. Sedangkan mentimun mercy mutan tingginya jauh lebih rendah dengan perlakuan yang sama. Dapat disimpulkan kombinasi perlakuan POC herbafarm (10 cc/l) dan dosis kompos TKKS (20 ton/ha) pada mentimun mercyF1 lebih baik pertumbuhan tinggi dari pada pada mentimun mercy mutan. Gambar 4.1 menunjukkan perbedaan tinggi antara mentimun mercy F1 yang berada dibaris sebelah kiri dalam plot dan mercy mutan baris sebelah kanan dalam plot.

Hasil penelitian Arif (2013), menunjukkan konsentrasi herbafarm $3 \mathrm{cc} / \mathrm{l}$ pada media tumbuh tanah gambut terhadap nanas berpengaruh terhadap tinggi, lebar daun, jumlah daun dan panjang akar. Selanjutnya penelitian Ramasadewo (2015) herbafarm 4 cc/1 berpengaruh nyata terhadap tinggi, umur berbunga, umur panen, berat buah pertanaman, jumlah buah pada tanaman sayur buah. Hal ini didukung penelitian Zulaikhah (2012), pemberian pupuk herbafarm berpengaruh nyata terhadap pertumbuhan vegetatif dan generatif tanaman pare dengan perlakuan terbaik konsentrasi herbafarm $4 \mathrm{cc} / \mathrm{l}$ air. Hasil yang sama juga diperoleh dari penelitian Nasri (2012), konsentrasi herbafarm $4 \mathrm{cc} / 1$ air berpengaruh nyata terhadap pertumbuhan dan hasil tanaman pare. Anonimus (2011), penambahan bio- protectant dalam herbafarm dapat meningkatkan sistem imunitas tanaman hingga tanaman dapat bertahan dan tetap sehat walaupun terjadi perubahan iklim yang drastis. 
Tabel4.1 Rerata tinggi tanaman $(\mathrm{cm})$ mentimun varietas mercy F1 (H_T_A1) dan mercy mutan (H_T_A2) dengan perlakuan POC herbafarm pupuk kompos TKKS

\begin{tabular}{|c|c|c|c|c|c|}
\hline No & $\begin{array}{c}\text { Kombinasi Herbafarm }(\mathrm{H}) \\
\text { dan Kompos TKKS }(\mathrm{T})\end{array}$ & Rerata & No & $\begin{array}{c}\text { Kombinasi Herbafarm }(\mathrm{H}) \text { dan } \\
\text { Kompos TKKS }(\mathrm{T})\end{array}$ & Rerata \\
\hline 1 & $10 \mathrm{ml} / 1 \mathrm{H}$ dan 20 ton $/$ ha $\mathrm{T}(\mathrm{A} 1)$ & $98.66 \pm 3.75 \mathrm{a}$ & 17 & $15 \mathrm{ml} / 1 \mathrm{H}$ dan 25 ton $/ \mathrm{ha} \mathrm{T} \mathrm{(A2)}$ & $70.33 \pm 4.63 \mathrm{~d}$ \\
\hline 2 & $15 \mathrm{ml} / 1 \mathrm{H}$ dan 25 ton $/$ ha $\mathrm{T} \mathrm{A} 1)$ & $97.33 \pm 7.42 \mathrm{ab}$ & 18 & $15 \mathrm{ml} / 1 \mathrm{H}$ dan 20 ton $/$ ha $\mathrm{T}$ (A2) & $69.66 \pm 3.38 \mathrm{~d}$ \\
\hline 3 & $15 \mathrm{ml} / 1 \mathrm{H}$ dan 15 ton $/$ ha $\mathrm{T}(\mathrm{A} 1)$ & $92.66 \pm 6.93 \mathrm{ab}$ & 19 & $10 \mathrm{ml} / 1 \mathrm{H}$ dan 20 ton $/ \mathrm{ha} \mathrm{T}(\mathrm{A} 2)$ & $67.66 \pm 3.66 \mathrm{de}$ \\
\hline 4 & $10 \mathrm{ml} / 1 \mathrm{H}$ dan 25 ton $/$ ha $\mathrm{T}(\mathrm{A} 1)$ & $92.66 \pm a b$ & 20 & $15 \mathrm{ml} / 1 \mathrm{H}$ dan 15 ton $/$ ha $\mathrm{T}$ (A2) & $67.33 \pm 5.69 \mathrm{de}$ \\
\hline 5 & $15 \mathrm{ml} / 1 \mathrm{H}$ dan 20 ton $/$ ha $\mathrm{T}$ (A1) & $90.66 \pm 2.96 \mathrm{abc}$ & 21 & $5 \mathrm{ml} / 1 \mathrm{H}$ dan 20 ton $/$ ha $\mathrm{T}$ (A2) & $67.00 \pm 3.21 \mathrm{de}$ \\
\hline 6 & $0 \mathrm{ml} / 1 \mathrm{H}$ dan 25 ton $/ \mathrm{ha} \mathrm{T}$ (A1) & $89.00 \pm 2.08 \mathrm{abc}$ & 22 & $5 \mathrm{ml} / 1 \mathrm{H}$ dan 25 ton $/$ ha $\mathrm{T}$ (A2) & $65.00 \pm 1.15 \mathrm{def}$ \\
\hline 7 & $5 \mathrm{ml} / 1 \mathrm{H}$ dan 25 ton $/ \mathrm{ha} \mathrm{T}(\mathrm{A} 1)$ & $87.00 \pm 1.73 \mathrm{bc}$ & 23 & $15 \mathrm{ml} / 1 \mathrm{H}$ dan 0 ton $/$ ha $\mathrm{T}$ (A2) & $64.00 \pm 0.57 \mathrm{def}$ \\
\hline 8 & $5 \mathrm{ml} / 1 \mathrm{H}$ dan 15 ton $/ \mathrm{ha} \mathrm{T}(\mathrm{A} 1)$ & $86.00 \pm 1.15 \mathrm{bc}$ & 24 & $10 \mathrm{ml} / 1 \mathrm{H}$ dan 15 ton $/$ ha $\mathrm{T}$ (A2) & $64.00 \pm 1.15 \mathrm{def}$ \\
\hline 9 & $10 \mathrm{ml} / 1 \mathrm{H}$ dan 15 ton $/$ ha $\mathrm{T}(\mathrm{A} 1)$ & $85.66 \pm 2.02 \mathrm{bc}$ & 25 & $10 \mathrm{ml} / 1 \mathrm{H}$ dan 25 ton $/ \mathrm{ha} \mathrm{T}(\mathrm{A} 2)$ & $64.00 \pm 0.57 \mathrm{def}$ \\
\hline 10 & $5 \mathrm{ml} / 1 \mathrm{H}$ dan 20 ton $/$ ha $\mathrm{T}$ (A1) & $84.66 \pm 1.76 \mathrm{bc}$ & 26 & $5 \mathrm{ml} / \mathrm{l} \mathrm{H}$ dan 15 ton $/$ ha $\mathrm{T}(\mathrm{A} 2)$ & $63.00 \pm 0.57 \mathrm{def}$ \\
\hline 11 & $15 \mathrm{ml} / 1 \mathrm{H}$ dan 0 ton $/$ ha $\mathrm{T}(\mathrm{A} 1)$ & $83.66 \pm 1.20 \mathrm{bc}$ & 27 & $0 \mathrm{ml} / 1 \mathrm{H}$ dan 15 ton $/ \mathrm{ha} \mathrm{T}$ (A2) & $62.66 \pm 1.76 \mathrm{def}$ \\
\hline 12 & $10 \mathrm{ml} / 1 \mathrm{H}$ dan 0 ton $/ \mathrm{ha} \mathrm{T}$ (A1) & $83.00 \pm 4.93 \mathrm{bc}$ & 28 & $0 \mathrm{ml} / 1 \mathrm{H}$ dan 0 ton $/ \mathrm{ha} \mathrm{T}(\mathrm{A} 2)$ & $61.66 \pm 3.17 \mathrm{def}$ \\
\hline 13 & $0 \mathrm{ml} / 1 \mathrm{H}$ dan 15 ton $/ \mathrm{ha} \mathrm{T}$ (A1) & $82.33 \pm 2.33 \mathrm{bc}$ & 29 & $0 \mathrm{ml} / 1 \mathrm{H}$ dan 25 ton $/$ ha $\mathrm{T}(\mathrm{A} 2)$ & $61.33 \pm 4.05 \mathrm{def}$ \\
\hline 14 & $0 \mathrm{ml} / 1 \mathrm{H}$ dan 0 ton $/ \mathrm{ha} \mathrm{T}(\mathrm{Al})$ & $81.66 \pm 1.20 \mathrm{c}$ & 30 & $0 \mathrm{ml} / 1 \mathrm{H}$ dan 20 ton $/ \mathrm{ha} \mathrm{T}(\mathrm{A} 2)$ & $60.33 \pm 3.28 \mathrm{def}$ \\
\hline 15 & $0 \mathrm{ml} / 1 \mathrm{H}$ dan 20 ton $/ \mathrm{ha} \mathrm{T}$ (A1) & $80.66 \pm 2.40 \mathrm{c}$ & 31 & $10 \mathrm{ml} / 1 \mathrm{H}$ dan 0 ton $/$ ha $\mathrm{T}(\mathrm{A} 2)$ & $57.33 \pm 2.40$ ef \\
\hline 16 & $5 \mathrm{ml} / 1 \mathrm{H}$ dan 0 ton $/$ ha $\mathrm{T}$ (A1) & $80.33 \pm 2.18 \mathrm{c}$ & 32 & $5 \mathrm{ml} / 1 \mathrm{H}$ dan 0 ton $/ \mathrm{ha} \mathrm{T}(\mathrm{A} 2)$ & $55.33 \pm 3.52 \mathrm{f}$ \\
\hline
\end{tabular}

Keterangan: Angka-angka pada kolom yang diikuti huruf kecil yang tidak sama menunjukkan berbeda nyata menurut uji lanjut DMRT $\mathrm{p}<0.05$. Tanda \pm adalah nilai standard error. A1: Mentimun F1, A2 : Mentimun

Penelitian penggunaan kompos TKKS yang dilakukan oleh Bariyanto dkk. (2015), menunjukkan peningkatan 40 ton/ha dosis kompos TKKS dapat meningkatkan tinggi bibit sawit. Respon kompos TKKS menunjukkan berbeda-beda untuk setiap spesies tanaman dalam pertumbuhannya. Oleh karena itu dosis maksimum tergantung dari keadaan fisiologi dan sifat genetik tanaman tersebut.

Umur berbunga (hari)

Interaksi perlakuan POC Herbafarm dan kompos TKKS mentimun mercy F1 menunjukkan terdapat perbedaan nyata pada parameter pengamatan umur berbunga seperti pada Tabel 4.2. Berdasarkan Tabel 4.2 kombinasi perlakuan $10 \mathrm{ml} / 1$ POC herbafarm dan 20 ton/ha kompos TKKS umur berbunga 28 hari setelah bibit mentimun F1 ditanam di plot perlakuan dan merupakan waktu tercepat dibandingkan dengan kombinasi perlakuan lain. Perbedaan umur berbunga dengan selisih rentang waktu 28-38 hari dan terdapat perbedaan umur berbunga antara 1-10 hari. Umumnya masa berbunga mentimun mercy F1 lebih cepat dibandingkan dengan mercy mutan. Perbedaan ciri marfologi dapat juga dilihat pada tinggi tanaman di bagian 4.1. Pembungaan mentimun mercy F1 mampu dipercepat dengan konsentrasi herbafarm 4-6 cc/l air dan dosis kompos TKKS 20-30 ton/ha.

Konsentrasi Herbafarm 6 cc/1 air mampu meningkatkan akumulasi bio-protectant dalam tanaman sehingga mampu meningkatkan sistem imunitas, daya tahan dan sistem transportasi hara dan asimilat menyebabkan tanaman mengoptimalkan faktor lingkungan seperti cahaya matahari, suhu, kelempan dan air untuk memacu pembungaan tanaman lebih cepat. Hasil penelitian Anjarwati (2014), menunjukkan pemberian Herbafarm $6 \mathrm{cc} / 1$ air mampu mempercepat pembungaan pada tanaman terung yaitu 38,67 hari. Penelitian sebelumnya oleh Rahmansyah dkk. (2012), menunjukkan bahwa pemberian konsentrasi POC 
Tabel 4.2 Rerata umur berbunga (hari) tanaman mentimun varietas mercy F1(H_T_A1) dan mercy mutan (H_T_A2) dengan perlakuan POC herbafarm pupuk kompos TKKS

\begin{tabular}{|c|c|c|c|c|c|}
\hline No & $\begin{array}{c}\text { Kombinasi Herbafarm }(\mathrm{H}) \\
\text { dan Kompos TKKS }(\mathrm{T})\end{array}$ & Rerata & No & $\begin{array}{c}\text { Kombinasi Herbafarm }(\mathrm{H}) \text { dan } \\
\text { Kompos TKKS (T) }\end{array}$ & Rerata \\
\hline 1 & $15 \mathrm{ml} / 1 \mathrm{H}$ dan 15 ton $/$ ha $\mathrm{T}(\mathrm{A} 1)$ & $28.00 \pm 1.15 \mathrm{a}$ & 17 & $0 \mathrm{ml} / 1 \mathrm{H}$ dan 20 ton $/$ ha $\mathrm{T}$ (A1) & $32.33 \pm 0.88$ defghij \\
\hline 2 & $10 \mathrm{ml} / 1 \mathrm{H}$ dan 20 ton $/ \mathrm{ha} \mathrm{T}(\mathrm{A} 1)$ & $28.00 \pm 1.15 \mathrm{a}$ & 18 & $0 \mathrm{ml} / 1 \mathrm{H}$ dan 0 ton $/ \mathrm{ha} \mathrm{T}$ (A1) & $33.00 \pm 0.57$ efghij \\
\hline 3 & $15 \mathrm{ml} / 1 \mathrm{H}$ dan 25 ton $/$ ha $\mathrm{T}$ (A1) & $29.33 \pm 1.20 \mathrm{abc}$ & 19 & $5 \mathrm{ml} / 1 \mathrm{H}$ dan 20 ton $/$ ha $\mathrm{T}$ (A2) & $33.33 \pm 0.66$ efghij \\
\hline 4 & $5 \mathrm{ml} / 1 \mathrm{H}$ dan 25 ton $/$ ha $\mathrm{T}(\mathrm{A} 1)$ & $29.33 \pm 1.45 \mathrm{abc}$ & 20 & $10 \mathrm{ml} / 1 \mathrm{H}$ dan 20 ton $/$ ha $\mathrm{T}(\mathrm{A} 2)$ & $34.00 \pm 1.00$ efghij \\
\hline 5 & $15 \mathrm{ml} / 1 \mathrm{H}$ dan 0 ton $/ \mathrm{ha} \mathrm{T}(\mathrm{A} 1)$ & $29.66 \pm 0.88 \mathrm{abc}$ & 21 & $15 \mathrm{ml} / 1 \mathrm{H}$ dan 25 ton $/ \mathrm{ha} \mathrm{T}$ (A2) & $34.33 \pm 0.33$ fghijk \\
\hline 6 & $15 \mathrm{ml} / 1 \mathrm{H}$ dan 20 ton $/ \mathrm{ha} \mathrm{T}$ (A1) & $29.66 \pm 1.76 \mathrm{abc}$ & 22 & $0 \mathrm{ml} / 1 \mathrm{H}$ dan 25 ton $/ \mathrm{ha} \mathrm{T}(\mathrm{A} 2)$ & $34.33 \pm 0.88$ ghijk \\
\hline 7 & $10 \mathrm{ml} / 1 \mathrm{H}$ dan 15 ton $/$ ha $\mathrm{T}$ (A1) & $30.33 \pm 0.66 \mathrm{abc}$ & 23 & $10 \mathrm{ml} / 1 \mathrm{H}$ dan 25 ton $/$ ha $\mathrm{T}$ (A2) & $34.66 \pm 0.66$ hijk \\
\hline 8 & $10 \mathrm{ml} / 1 \mathrm{H}$ dan 0 ton $/ \mathrm{ha} \mathrm{T}(\mathrm{A} 1)$ & $30.33 \pm 1.45 \mathrm{abcd}$ & 24 & $15 \mathrm{ml} / 1 \mathrm{H}$ dan 25 ton $/$ ha $\mathrm{T}$ (A2) & $35.00 \pm 1.73$ hijk \\
\hline 9 & $10 \mathrm{ml} / 1 \mathrm{H}$ dan 25 ton $/$ ha $\mathrm{T}(\mathrm{A} 1)$ & $30.33 \pm 0.88$ abcde & 25 & $0 \mathrm{ml} / 1 \mathrm{H}$ dan 15 ton $/$ ha $\mathrm{T}(\mathrm{A} 2)$ & $35.66 \pm 0.88$ hijk \\
\hline 10 & $5 \mathrm{ml} / \mathrm{l} \mathrm{H}$ dan 20 ton /ha T (A1) & $30.33 \pm 1.45$ abcdef & 26 & $10 \mathrm{ml} / 1 \mathrm{H}$ dan 15 ton $/$ ha $\mathrm{T}$ (A2) & $36.00 \pm 1.52$ hijk \\
\hline 11 & $5 \mathrm{ml} / 1 \mathrm{H}$ dan 0 ton $/ \mathrm{ha} \mathrm{T}(\mathrm{A} 1)$ & $31.00 \pm 1.15$ abcdef & 27 & $5 \mathrm{ml} / 1 \mathrm{H}$ dan 0 ton $/$ ha $\mathrm{T}(\mathrm{A} 2)$ & $36.33 \pm 0.33 \mathrm{ijk}$ \\
\hline 12 & $0 \mathrm{ml} / 1 \mathrm{H}$ dan 25 ton $/$ ha $\mathrm{T}$ (A1) & $31.33 \pm 1.20$ bcdefg & 28 & $0 \mathrm{ml} / 1 \mathrm{H}$ dan 0 ton $/$ ha $\mathrm{T}(\mathrm{A} 2)$ & $36.33 \pm 0.66 \mathrm{ijk}$ \\
\hline 13 & $15 \mathrm{ml} / 1 \mathrm{H}$ dan 15 ton $/$ ha $\mathrm{T}(\mathrm{A} 2)$ & $31.66 \pm 2.07$ bcdefg & 29 & $0 \mathrm{ml} / 1 \mathrm{H}$ dan 20 ton $/ \mathrm{ha} \mathrm{T}(\mathrm{A} 2)$ & $36.33 \pm 1.20 \mathrm{jk}$ \\
\hline 14 & $5 \mathrm{ml} / 1 \mathrm{H}$ dan 15 ton $/$ ha $\mathrm{T}(\mathrm{A} 1)$ & $31.66 \pm 1.45$ cdefgh & 30 & $5 \mathrm{ml} / 1 \mathrm{H}$ dan 15 ton/ha $\mathrm{T}(\mathrm{A} 2)$ & $36.33 \pm 1.20 \mathrm{jk}$ \\
\hline 15 & $0 \mathrm{ml} / 1 \mathrm{H}$ dan 15 ton $/ \mathrm{ha} \mathrm{T}$ (A1) & $31.66 \pm 1.20$ cdefghi & 31 & $5 \mathrm{ml} / 1 \mathrm{H}$ dan 25 ton $/$ ha $\mathrm{T}$ (A2) & $37.33 \pm 0.66 \mathrm{k}$ \\
\hline 16 & $15 \mathrm{ml} / 1 \mathrm{H}$ dan 20 ton $/ \mathrm{ha} \mathrm{T}$ (A2) & $32.33 \pm 1.33$ defghij & 32 & $10 \mathrm{ml} / 1 \mathrm{H}$ dan 0 ton $/ \mathrm{ha} \mathrm{T}(\mathrm{A} 2)$ & $38.00 \pm 0.57 \mathrm{k}$ \\
\hline
\end{tabular}

Keterangan: Angka-angka pada kolom yang diikuti huruf kecil yang tidak sama menunjukkan berbeda nyata menurut uji lanjut DMRT $\mathrm{p}<0.05$. Tanda \pm adalah nilai standard error. A1: Mentimun F1, A2 : Mentimun

Tabel 4.3 Rerata jumlah buah per tanaman mentimun varietas mercy (H_T_A1) dan mercy mutan (H_T_A2) dengan perlakuan POC herbafarm pupuk kompos TKKS.

\begin{tabular}{|c|c|c|c|c|c|}
\hline No & $\begin{array}{c}\text { Kombinasi Herbafarm }(\mathrm{H}) \\
\text { dan Kompos TKKS }(\mathrm{T})\end{array}$ & Rerata & No & $\begin{array}{c}\text { Kombinasi Herbafarm }(\mathrm{H}) \text { dan } \\
\text { Kompos TKKS }(\mathrm{T})\end{array}$ & Rerata \\
\hline 1 & $15 \mathrm{ml} / 1 \mathrm{H}$ dan 25 ton $/$ ha $\mathrm{T}$ (A2) & $7.33 \pm 0.16 \mathrm{a}$ & 17 & $5 \mathrm{ml} / 1 \mathrm{H}$ dan 0 ton $/ \mathrm{ha} \mathrm{T} \mathrm{(A1)}$ & $5.00 \pm 0.16 \mathrm{cdefg}$ \\
\hline 2 & $15 \mathrm{ml} / 1 \mathrm{H}$ dan 15 ton $/$ ha $\mathrm{T}(\mathrm{A} 2)$ & $6.66 \pm 0.16 \mathrm{ab}$ & 18 & $15 \mathrm{ml} / 1 \mathrm{H}$ dan 20 ton $/$ ha $\mathrm{T}(\mathrm{A} 1)$ & $5.00 \pm 0.16$ cdefg \\
\hline 3 & $10 \mathrm{ml} / 1 \mathrm{H}$ dan 25 ton $/$ ha $\mathrm{T}$ (A1) & $6.33 \pm 0.28 \mathrm{abc}$ & 19 & $5 \mathrm{ml} / 1 \mathrm{H}$ dan 0 ton $/$ ha $\mathrm{T}(\mathrm{A} 2)$ & $5.00 \pm 0.44$ cdefg \\
\hline 4 & $15 \mathrm{ml} / 1 \mathrm{H}$ dan 0 ton $/ \mathrm{ha} \mathrm{T}(\mathrm{A} 2)$ & $6.33 \pm 0.28 \mathrm{abc}$ & 20 & $0 \mathrm{ml} / 1 \mathrm{H}$ dan 25 ton $/$ ha $\mathrm{T}(\mathrm{A} 2)$ & $5.00 \pm 0.44$ cdefg \\
\hline 5 & $15 \mathrm{ml} / 1 \mathrm{H}$ dan 20 ton $/$ ha $\mathrm{T}$ (A2) & $6.33 \pm 0.16 \mathrm{abc}$ & 21 & $10 \mathrm{ml} / 1 \mathrm{H}$ dan 15 ton $/$ ha $\mathrm{T}$ (A1) & $4.66 \pm 0.16$ defgh \\
\hline 6 & $10 \mathrm{ml} / 1 \mathrm{H}$ dan 25 ton/ha $\mathrm{T}(\mathrm{A} 2)$ & $6.33 \pm 0.28 \mathrm{abc}$ & 22 & $0 \mathrm{ml} / 1 \mathrm{H}$ dan 25 ton $/ \mathrm{ha} \mathrm{T}$ (A1) & $4.66 \pm 0.16$ defgh \\
\hline 7 & $15 \mathrm{ml} / 1 \mathrm{H}$ dan 25 ton $/$ ha $\mathrm{T}$ (A1) & $6.00 \pm 0.44 \mathrm{abcd}$ & 23 & $5 \mathrm{ml} / 1 \mathrm{H}$ dan 25 ton $/$ ha $\mathrm{T}$ (A1) & $4.66 \pm 0.16$ defgh \\
\hline 8 & $10 \mathrm{ml} / 1 \mathrm{H}$ dan 20 ton $/$ ha $\mathrm{T}(\mathrm{A} 2)$ & $6.00 \pm 0.16 \mathrm{abcd}$ & 24 & $5 \mathrm{ml} / 1 \mathrm{H}$ dan 15 ton $/ \mathrm{ha} \mathrm{T}(\mathrm{A} 2)$ & $4.66 \pm 0.50$ defgh \\
\hline 9 & $10 \mathrm{ml} / 1 \mathrm{H}$ dan 20 ton $/$ ha $\mathrm{T}(\mathrm{A} 1)$ & $5.66 \pm 0.44$ bcde & 25 & $0 \mathrm{ml} / 1 \mathrm{H}$ dan 20 ton $/ \mathrm{ha} \mathrm{T}(\mathrm{A} 2)$ & $4.33 \pm 0.33$ efgh \\
\hline 10 & $5 \mathrm{ml} / 1 \mathrm{H}$ dan 15 ton $/$ ha $\mathrm{T}(\mathrm{A} 2)$ & $5.66 \pm 0.28$ bcde & 26 & $10 \mathrm{ml} / 1 \mathrm{H}$ dan 0 ton $/ \mathrm{ha} \mathrm{T}(\mathrm{A} 1)$ & $4.00 \pm 0.57 \mathrm{fgh}$ \\
\hline 11 & $15 \mathrm{ml} / 1 \mathrm{H}$ dan 0 ton $/$ ha $\mathrm{T}$ (A1) & $5.33 \pm 0.28$ bcdef & 27 & $15 \mathrm{ml} / 1 \mathrm{H}$ dan 15 ton $/$ ha $\mathrm{T}$ (A1) & $4.00 \pm 0.28 \mathrm{fgh}$ \\
\hline 12 & $5 \mathrm{ml} / 1 \mathrm{H}$ dan 15 ton $/$ ha $\mathrm{T}$ (A1) & $5.33 \pm 0.28$ bcdef & 28 & $0 \mathrm{ml} / 1 \mathrm{H}$ dan 0 ton $/ \mathrm{ha} \mathrm{T}$ (A2) & $4.00 \pm 0.16 \mathrm{fgh}$ \\
\hline 13 & $10 \mathrm{ml} / 1 \mathrm{H}$ dan 0 ton $/$ ha $\mathrm{T}$ (A2) & $5.33 \pm 0.76$ bcdef & 29 & $0 \mathrm{ml} / 1 \mathrm{H}$ dan 20 ton $/ \mathrm{ha} \mathrm{T}$ (A1) & $3.66 \pm 0.33 \mathrm{gh}$ \\
\hline 14 & $5 \mathrm{ml} / 1 \mathrm{H}$ dan 20 ton $/ \mathrm{ha} \mathrm{T}$ (A2) & $5.33 \pm 0.16$ bcdef & 30 & $0 \mathrm{ml} / 1 \mathrm{H}$ dan 15 ton $/$ ha $\mathrm{T}$ (A1) & $3.66 \pm 0.28 \mathrm{gh}$ \\
\hline 15 & $0 \mathrm{ml} / 1 \mathrm{H}$ dan 15 ton $/$ ha $\mathrm{T}(\mathrm{A} 2)$ & $5.33 \pm 0.28$ bcdef & 31 & $0 \mathrm{ml} / 1 \mathrm{H}$ dan 0 ton $/ \mathrm{ha} \mathrm{T}(\mathrm{A} 1)$ & $3.33 \pm 0.44 \mathrm{~h}$ \\
\hline 16 & $10 \mathrm{ml} / 1 \mathrm{H}$ dan 15 ton $/$ ha $\mathrm{T}(\mathrm{A} 2)$ & $5.33 \pm 0.28$ bcdef & 32 & $5 \mathrm{ml} / 1 \mathrm{H}$ dan 20 ton $/ \mathrm{ha} \mathrm{T}(\mathrm{A} 1)$ & $3.33 \pm 0.33 \mathrm{~h}$ \\
\hline
\end{tabular}

Keterangan: Angka-angka pada kolom yang diikuti huruf kecil yang tidak sama menunjukkan berbeda nyata menurut uji lanjut DMRT $\mathrm{p}<0.05$. Tanda \pm adalah nilai standard error. A1: Mentimun F1, A2 : Mentimun

herbafarm $6 \mathrm{cc} / 1$ air memberikan pengaruh terbaik terhadap umur berbunga tanaman yaitu 28,67 hari.

Pemberian kompos TKKS pada tanah sebagai amelioran menyebabkan kandungan unsur hara makro dan mikro bertambah banyak serta menyumbangkan humus tanah. Hal ini sesuai dengan pendapat
Firmansyah (2010) kompos adalah produk yang dihasilkan dari pelapukan atau dekomposisi sisa-sisa bahan organik secara biologi yang terkontrol menjadi bagian-bagian yang dihumuskan. Diduga pada benih mentimun mercy mutan pada penelitian ini hasil perlakuan mutasi dengan kolkisin menyebabkan jumlah 


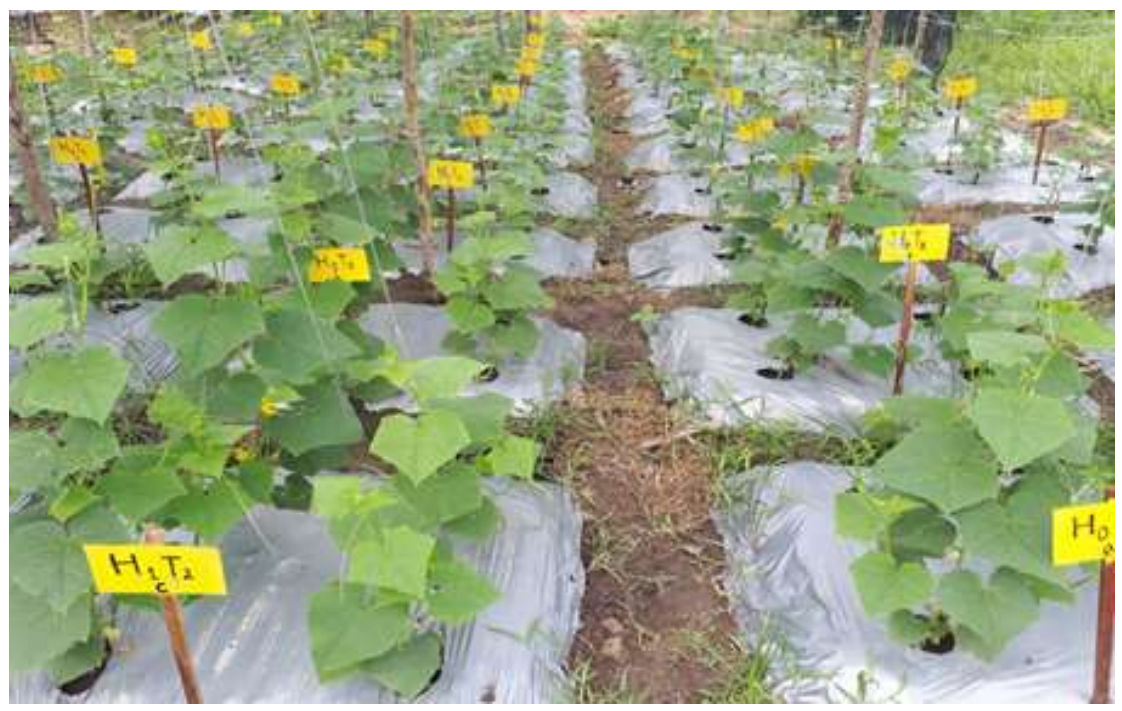

Gambar 4.1 Pertumbuhan tanaman mentimun mercy F1 (baris A) dan mercy mutan (baris B) umur 22 hari setelah tanam.

sebaran stomata menurun. Pengaruh pada anggrek bulan persentase hidup menurun (Rahayu dkk. 2015). Penelitian lain konsentrasi kolkisin $0,20 \%$ adalah konsentrasi tertinggi yang mengakibatkan penurunan pertumbuhan, namun meningkatkan kandungan protein biji kacang hijau. Berdasarkan hasil penelitian sebelumnya pada beberapajenis tanaman menunjukkan terdapat terdapat peningkatan pertumbuhan vegetatif, seperti kacang hijau, kedelai dan jagung. Kolkisin menyebabkan penurunan pertumbuhan vegetatif pada anggrek bulan (Rahayu dkk. 2015), juga ganyong (Rahman dkk. 2017).

\section{Jumlah buah per tanaman}

Interaksi perlakuan POC Herbafarm dan pupuk kompos TKKS pada tanaman mentimun mercy F1 dan mercy mutan menunjukkan berbeda nyata pada parameter pengamatan jumlah buah seperti dapat dilihat pada Tabel 4.3. Berdasarkan Tabel 4.2 kombinasi perlakuan $15 \mathrm{ml} / 1$ POC herbafarm dan 25 ton/ha kompos TKKS (7.33 buah) serta $15 \mathrm{ml} / 1$ POC herbafarm dan 15 ton/ha kompos TKKS (6.66 buah) pada tanaman mercy mutan dengan jumlah buah per tanaman lebih tinggi dibandingkan mercy F1.

Dosis herbafarm $6 \mathrm{cc} / \mathrm{l}$ air dapat meningkatkan akumulasi bio-protectant dan meningkatkan sistem imunitas yang menyebabkan tanaman mengoptimalkan faktor lingkungan seperti cahaya matahari, suhu, kelempan dan air untuk memacu pembentukan buah yang lebih banyak. Penelitian Setyoko dkk. (2012), pupuk POC herbafarm $6 \mathrm{cc} / \mathrm{l}$ air memberikan pengaruh nyata terhadap peningkatan jumlah buah. Konsentrasi POC herbafarm $6 \mathrm{cc} / 1$ air memberikan pengaruh yang baik terhadap reaksi-reaksi metabolisme dalam tubuh tanaman hortikultura contohnya blustru sehingga terjadi peningkatan jumlah bunga dan tingkat keberhasilan polinasi yang menyebabkan jumlah buah blustru menjadi meningkat. Penelitian Rahmansyah dkk. (2012), menunjukkan bahwa pemberian pupuk herbafarm $6 \mathrm{cc} / 1$ air memberikan pengaruh terbaik 
terhadap tanaman pare yaitu 28,67 hari.

Peningkatan produksi mentimun pada perlakuan kompos TKKS adalah sangat baik (Permanasari dan Annisava 2015). Pemberian kompos TKKS dapat meningkatkan produksi buah mentimun dan terdapat kesejajaran dengan pupuk kandang ayam meskipun secara angka jumlahnya di bawah pupuk kandang ayam (Purnamayani dkk. 2012). Hasil penelitian Rahman dkk (2017) menunjukkan jumlah buah perbatang dengan konsentrasi kolkisin 6\% menurunkan menurunkan hasil. Penelitian konsentrasi kolkisin $0.5 \%$ pada mercy mutan menunjukkan buah yang lebih banyak dibandingkan mercy F1 6 cc/1 air telah mampu mempercepat pembentukan buah pada umur 38,67 hari.

\section{Berat buah per tanaman (g)}

Interaksi perlakuan POC Herbafarm dan pupuk kompos TKKS pada tanaman mentimun menunjukkan terdapat berbeda nyata pada parameter pengamatan jumlah buah seperti dapat dilihat pada Tabel 4.4. Berdasarkan Tabel 4.4 kombinasi perlakuan $15 \mathrm{ml} / 1$ POC herbafarm dan 25 ton/ha kompos TKKS menghasilkan 1447.67 g. Selanjutnya 15 ml/1 POC herbafarm dan 20 ton/ha kompos TKKS menghasilkan 1431.83 g. Pada mentimun varietas mercy F1 berat buah per tanaman lebih tinggi dibandingkan mercy mutan. Jumlah buah mercy mutan (Tabel 4.3) meskipun lebih banyak, namun ukuran buahnya lebih kecil sehingga lebih ringan buahnya.

Penelitian Setyoko dkk. (2012), pupuk POC herbafarm konsentrasi $6 \mathrm{cc} / 1$ air memberikan pengaruh nyata terhadap peningkatan jumlah buah. Konsentrasi $6 \mathrm{cc} / 1$ air berpengaruh positif terhadap reaksi-reaksi penguraian dalam tubuh tanaman sehingga terjadi peningkatan jumlah bunga dan tingkat keberhasilan polinasi yang menyebabkan jumlah buah meningkat. Penelitian sebelumnya oleh Rahmansyah dkk. (2012),

Tabel 4.4 Berat buah $(\mathrm{kg})$ per tanaman mentimun varietas mercy F1(H_T_A1) dan mutan mercy (H_T_A2) dengan perlakuan POC herbafarm pupuk kompos TKKS

\begin{tabular}{|c|c|c|c|c|c|}
\hline No & $\begin{array}{c}\text { Kombinasi Herbafarm }(\mathrm{H}) \\
\text { dan Kompos TKKS }(\mathrm{T})\end{array}$ & Rerata & No & $\begin{array}{c}\text { Kombinasi Herbafarm }(\mathrm{H}) \\
\text { dan Kompos TKKS }(\mathrm{T})\end{array}$ & Rerata \\
\hline 1 & $15 \mathrm{ml} / 1 \mathrm{H}$ dan 25 ton $/$ ha $\mathrm{T}(\mathrm{A} 1)$ & $1.44 \pm 44.73 \mathrm{a}$ & 17 & $15 \mathrm{ml} / \mathrm{l} \mathrm{H}$ dan 0 ton $/ \mathrm{ha} \mathrm{T}(\mathrm{A} 1)$ & $0.99 \pm 57.50$ \\
\hline 2 & $15 \mathrm{ml} / \mathrm{l} \mathrm{H}$ dan 20 ton $/$ ha $\mathrm{T}$ (A1) & $1.43 \pm 39.99 \mathrm{ab}$ & 18 & $5 \mathrm{ml} / 1 \mathrm{H}$ dan 15 ton $/$ ha $\mathrm{T}$ (A1) & $0.98 \pm 80.16$ defghijk \\
\hline 3 & $15 \mathrm{ml} / \mathrm{l} \mathrm{H}$ dan 25 ton $/$ ha $\mathrm{T}$ (A2) & $1.24 \pm 49.65 \mathrm{bc}$ & 19 & $10 \mathrm{ml} / 1 \mathrm{H}$ dan 0 ton $/ \mathrm{ha} \mathrm{T}$ (A1) & $0.97 \pm 35.59$ defghijkl \\
\hline 4 & $10 \mathrm{ml} / 1 \mathrm{H}$ dan 25 ton $/ \mathrm{ha} \mathrm{T}$ (A1) & $1.17 \pm 107.34 \mathrm{~cd}$ & 20 & $0 \mathrm{ml} / 1 \mathrm{H}$ dan 20 ton $/ \mathrm{ha} \mathrm{T}$ (A2) & $0.95 \pm 50.60$ fghijkl \\
\hline 5 & $5 \mathrm{ml} / 1 \mathrm{H}$ dan 25 ton $/ \mathrm{ha} \mathrm{T}(\mathrm{A} 1)$ & $1.16 \pm 63.94 \mathrm{cde}$ & 21 & $5 \mathrm{ml} / 1 \mathrm{H}$ dan 20 ton $/$ ha $\mathrm{T}$ (A1) & $0.92 \pm 136.92$ fghijklm \\
\hline 6 & $10 \mathrm{ml} / 1 \mathrm{H}$ dan 20 ton $/ \mathrm{ha} \mathrm{T}$ (A1) & $1.14 \pm 107.24 \mathrm{cdef}$ & 22 & $5 \mathrm{ml} / 1 \mathrm{H}$ dan 15 ton $/ \mathrm{ha} \mathrm{T}$ (A2) & $0.88 \pm 94.27$ ghijklm \\
\hline 7 & $10 \mathrm{ml} / 1 \mathrm{H}$ dan 25 ton $/ \mathrm{ha} \mathrm{T}$ (A2) & $1.08 \pm 111.31 \mathrm{cdefg}$ & 23 & $5 \mathrm{ml} / 1 \mathrm{H}$ dan 25 ton $/ \mathrm{ha} \mathrm{T}$ (A2) & $0.86 \pm 64.14$ ghijklm \\
\hline 8 & $10 \mathrm{ml} / \mathrm{l} \mathrm{H}$ dan 15 ton/ha $\mathrm{T}(\mathrm{A} 1)$ & $1.08 \pm 44.94 \mathrm{cdefg}$ & 24 & $5 \mathrm{ml} / 1 \mathrm{H}$ dan 0 ton $/$ ha $\mathrm{T}$ (A1) & $0.84 \pm 54.54$ hijklm \\
\hline 9 & $10 \mathrm{ml} / 1 \mathrm{H}$ dan 0 ton/ha $\mathrm{T}$ (A2) & $1.07 \pm 50.41 \mathrm{cdefg}$ & 25 & $15 \mathrm{ml} / \mathrm{l} \mathrm{H}$ dan 15 ton $/$ ha $\mathrm{T}$ (A2) & $0.84 \pm 51.47$ hijklm \\
\hline 10 & $15 \mathrm{ml} / 1 \mathrm{H}$ dan 20 ton $/$ ha $\mathrm{T}(\mathrm{A} 2)$ & $1.05 \pm 46.36$ cdefgh & 26 & $0 \mathrm{ml} / 1 \mathrm{H}$ dan 25 ton $/ \mathrm{ha} \mathrm{T}(\mathrm{A} 1)$ & $0.83 \pm 45.02$ hijklm \\
\hline 11 & $15 \mathrm{ml} / \mathrm{l} \mathrm{H}$ dan 0 ton $/ \mathrm{ha} \mathrm{T}$ (A2) & $1.05 \pm 48.73$ cdefgh & 27 & $0 \mathrm{ml} / 1 \mathrm{H}$ dan 0 ton $/$ ha $\mathrm{T}(\mathrm{A} 1)$ & $0.82 \pm 30.58 \mathrm{ijklm}$ \\
\hline 12 & $15 \mathrm{ml} / \mathrm{l} \mathrm{H}$ dan 15 ton /ha T (A1) & $1.04 \pm 25.86$ cdefghi & 28 & $0 \mathrm{ml} / 1 \mathrm{H}$ dan 15 ton $/ \mathrm{ha} \mathrm{T}(\mathrm{A} 1)$ & $0.80 \pm 84.74 \mathrm{ijklm}$ \\
\hline 13 & $10 \mathrm{ml} / \mathrm{l} \mathrm{H}$ dan 20 ton $/$ ha $\mathrm{T}$ (A2) & $1.03 \pm 86.71$ cdefghi & 29 & $0 \mathrm{ml} / 1 \mathrm{H}$ dan 15 ton $/ \mathrm{ha} \mathrm{T}(\mathrm{A} 2)$ & $0.79 \pm 45.48 \mathrm{klm}$ \\
\hline 14 & $0 \mathrm{ml} / 1 \mathrm{H}$ dan 25 ton $/$ ha $\mathrm{T}(\mathrm{A} 2)$ & $1.02 \pm 39.30$ defghij & 30 & $0 \mathrm{ml} / 1 \mathrm{H}$ dan 0 ton $/ \mathrm{ha} \mathrm{T}(\mathrm{A} 2)$ & $0.78 \pm 83.86 \mathrm{klm}$ \\
\hline 15 & $0 \mathrm{ml} / 1 \mathrm{H}$ dan 20 ton $/ \mathrm{ha} \mathrm{T}$ (A1) & $1.00 \pm 33.51$ defghijk & 31 & $5 \mathrm{ml} / 1 \mathrm{H}$ dan 0 ton $/ \mathrm{ha} \mathrm{T}(\mathrm{A} 2)$ & $0.76 \pm 45.73 \mathrm{~lm}$ \\
\hline 16 & $5 \mathrm{ml} / 1 \mathrm{H}$ dan 20 ton $/ \mathrm{ha} \mathrm{T}(\mathrm{A} 2)$ & $0.99 \pm 32.21$ defghijk & 32 & $10 \mathrm{ml} / 1 \mathrm{H}$ dan 15 ton $/$ ha $\mathrm{T}$ (A2) & $0.710 .00 \pm 45.36 \mathrm{~m}$ \\
\hline
\end{tabular}

Keterangan: Angka-angka pada kolom yang diikuti huruf kecil yang tidak sama menunjukkan berbeda nyata menurut uji lanjut DMRT $\mathrm{p}<0.05$. Tanda \pm adalah nilai standard error. A1: Mentimun F1, A2 : Mentimun 
menunjukkan herbafarm $6 \mathrm{cc} / 1$ air memberikan pengaruh terbaik terhadap fase generatif.

Hasil penelitian Zulaikhah (2012), sistem transportasi unsur hara mempengaruhi proses penyebaran asimilat keseluruhan bagian tanaman lebih meningkatkan produksi. Bobot buah dipengaruhi oleh banyaknya akumulasi asimilat. Semakin tinggi asimilatyang dihasilkan maka akumulasi asimilat di dalam buah menjadi tinggi dan dapat meningkatkan berat buah(Zulkarneani, 2011).

\section{Panjang buah (cm)}

Interaksi perlakuan POC Herbafarm dan pupuk kompos TKKS pada tanaman mentimun menunjukkan terdapat berbeda nyata pada parameter panjang buah seperti dapat dilihat pada Tabel 4.5. Berdasarkan Tabel 4.5 dapat dilihat kombinasi perlakuan $10 \mathrm{ml} / 1$ POC herbafarm dan 20 ton/ha kompos TKKS menghasilkan panjang buah $24.50 \mathrm{~cm}$ serta $10 \mathrm{ml} / 1$ POC herbafarm dan 25 ton/ha kompos
TKKS menghasilkan panjang buah $23.66 \mathrm{~cm}$ pada tanaman varietas mercy F1. Panjang rerata mentimun mercyF1 lebih tinggi secara keseluruhan dibandingkan mercy mutasi. Panjang buah mercy mutan lebih ditentukan karena pengaruh genetik dapat dilihat pada Gambar 4.2. Berdasarkan pengamatan sebelumnya ciri mentimun mercy mutan adalah berukuran lebih pendek, lebih kecil dari pada mercy F1.

Sebagai perbandingan perlakuan jenis POC dan konsentrasi yang berbeda pada mentimun mercy F1 panjang tertinggi $21.5 \mathrm{~cm}$ (Andrie dkk.2015). Hasil penelitan tersebut panjang buah lebih rendah dari pada penelitian ini. Namunjika dibandingkan dengan mercy mutan masih lebih panjang. Penelitian Abdurrazak dkk. (2013), panjang buah dipengaruhi jarak tanaman, semakin jarang jarak tanam maka buah semakin panjang. Hal ini disebabkan jarak tanam yang jarang tanah sebagai media tanam menyediakan unsur hara yang lebih banyak.

Tabel 4.5 Rerata panjang buah (cm) per tanaman mentimun varietas mercy F1 (H_T_A1) dan mutan mercy (H_T_A2) dengan perlakuan POC herbafarm pupuk kompos TKKS.

\begin{tabular}{|c|c|c|c|c|c|}
\hline No & $\begin{array}{c}\text { Kombinasi Herbafarm }(\mathrm{H}) \\
\text { dan Kompos TKKS }(\mathrm{T})\end{array}$ & Rerata & No & $\begin{array}{c}\text { Kombinasi Herbafarm }(\mathrm{H}) \\
\text { dan Kompos TKKS }(\mathrm{T})\end{array}$ & Rerata \\
\hline 1 & $10 \mathrm{ml} / 1 \mathrm{H}$ dan 20 ton $/$ ha $\mathrm{T}(\mathrm{A} 1)$ & $24.50 \pm 0.28 \mathrm{a}$ & 17 & $15 \mathrm{ml} / 1 \mathrm{H}$ dan 25 ton $/$ ha $\mathrm{T}$ (A2) & $17.33 \pm 0.66$ hij \\
\hline 2 & $10 \mathrm{ml} / 1 \mathrm{H}$ dan 25 ton $/$ ha $\mathrm{T}(\mathrm{A} 1)$ & $23.83 \pm 0.72 \mathrm{ab}$ & 18 & $5 \mathrm{ml} / 1 \mathrm{H}$ dan 15 ton ha $\mathrm{T}$ (A2) & $16.66 \pm 0.33 \quad \mathrm{ijk}$ \\
\hline 3 & $5 \mathrm{ml} / 1 \mathrm{H}$ dan 20 ton $/ \mathrm{ha} \mathrm{T}(\mathrm{A} 1)$ & $23.66 \pm 1.20 \mathrm{abc}$ & 19 & $15 \mathrm{ml} / 1 \mathrm{H}$ dan 15 ton $/$ ha $\mathrm{T}(\mathrm{A} 2)$ & $16.66 \pm 0.88 \mathrm{ijk}$ \\
\hline 4 & $5 \mathrm{ml} / 1 \mathrm{H}$ dan 15 ton $/ \mathrm{ha} \mathrm{T}$ (A1) & $23.66 \pm 1.76 \mathrm{abc}$ & 20 & $10 \mathrm{ml} / 1 \mathrm{H}$ dan 25 ton $/$ ha T (A2) & $16.66 \pm 1.33 \mathrm{ijk}$ \\
\hline 5 & $15 \mathrm{ml} / 1 \mathrm{H}$ dan 15 ton $/$ ha $\mathrm{T}$ (A1) & $23.66 \pm 0.16 \mathrm{abc}$ & 21 & $5 \mathrm{ml} / 1 \mathrm{H}$ dan 20 ton $/$ ha $\mathrm{T}$ (A2) & $16.00 \pm 0.57 \mathrm{jkl}$ \\
\hline 6 & $10 \mathrm{ml} / 1 \mathrm{H}$ dan 0 ton $/ \mathrm{ha} \mathrm{T}$ (A1) & $23.50 \pm 0.76 \mathrm{abcd}$ & 22 & $0 \mathrm{ml} / 1 \mathrm{H}$ dan 25 ton $/$ ha $\mathrm{T}$ (A2) & $15.66 \pm 0.66 \mathrm{jklm}$ \\
\hline 7 & $15 \mathrm{ml} / 1 \mathrm{H}$ dan 25 ton $/$ ha $\mathrm{T}$ (A1) & $23.50 \pm 0.76$ abcd & 23 & $5 \mathrm{ml} / 1 \mathrm{H}$ dan 25 ton ha $\mathrm{T}$ (A2) & $15.66 \pm 0.88 \mathrm{jklm}$ \\
\hline 8 & $15 \mathrm{ml} / 1 \mathrm{H}$ dan 20 ton $/$ ha $\mathrm{T}$ (A1) & $23.00 \pm 1.15$ abcde & 24 & $10 \mathrm{ml} / 1 \mathrm{H}$ dan 20 ton $/$ ha $\mathrm{T}(\mathrm{A} 2)$ & $15.33 \pm 0.66 \mathrm{jklm}$ \\
\hline 9 & $0 \mathrm{ml} / 1 \mathrm{H}$ dan 25 ton $/$ ha $\mathrm{T}(\mathrm{A} 1)$ & $22.66 \pm 0.33$ abcde & 25 & $15 \mathrm{ml} / 1 \mathrm{H}$ dan 20 ton $/$ ha T (A2) & $15.00 \pm 0.57 \mathrm{jklmn}$ \\
\hline 10 & $0 \mathrm{ml} / \mathrm{l} \mathrm{H}$ dan 0 ton $/$ ha $\mathrm{T}(\mathrm{A} 1)$ & $21.83 \pm 0.88$ bcdef & 26 & $15 \mathrm{ml} / 1 \mathrm{H}$ dan 0 ton $/$ ha $\mathrm{T}(\mathrm{A} 2)$ & $14.66 \pm 1.33 \mathrm{klmn}$ \\
\hline 11 & $5 \mathrm{ml} / 1 \mathrm{H}$ dan 25 ton $/$ ha $\mathrm{T}$ (A1) & $21.16 \pm 1.01 \mathrm{cdefg}$ & 27 & $0 \mathrm{ml} / 1 \mathrm{H}$ dan 20 ton $/ \mathrm{ha} \mathrm{T}$ (A2) & $14.33 \pm 0.88 \mathrm{klmn}$ \\
\hline 12 & $15 \mathrm{ml} / 1 \mathrm{H}$ dan 0 ton $/$ ha $\mathrm{T}$ (A1) & $21.00 \pm 1.15 \mathrm{defg}$ & 28 & $10 \mathrm{ml} / 1 \mathrm{H}$ dan 15 ton $/$ ha $\mathrm{T}(\mathrm{A} 2)$ & $14.33 \pm 0.88 \mathrm{klmn}$ \\
\hline 13 & $0 \mathrm{ml} / 1 \mathrm{H}$ dan 20 ton $/$ ha $\mathrm{T}$ (A1) & $20.66 \pm 0.66 \mathrm{efg}$ & 29 & $5 \mathrm{ml} / 1 \mathrm{H}$ dan 0 ton $/$ ha $\mathrm{T}(\mathrm{A} 2)$ & $14.00 \pm 0.57 \mathrm{klmn}$ \\
\hline 14 & $10 \mathrm{ml} / 1 \mathrm{H}$ dan 15 ton $/$ ha $\mathrm{T}$ (A1) & $19.33 \pm 0.33 \mathrm{fgh}$ & 30 & $0 \mathrm{ml} / 1 \mathrm{H}$ dan 15 ton $/$ ha $\mathrm{T}(\mathrm{A} 2)$ & $13.66 \pm 0.33 \mathrm{lmn}$ \\
\hline 15 & $5 \mathrm{ml} / 1 \mathrm{H}$ dan 0 ton $/ \mathrm{ha} \mathrm{T}(\mathrm{A} 1)$ & $19.33 \pm 0.88 \mathrm{fgh}$ & 31 & $0 \mathrm{ml} / 1 \mathrm{H}$ dan 0 ton $/ \mathrm{ha} \mathrm{T}(\mathrm{A} 2)$ & $13.16 \pm 0.60 \mathrm{mn}$ \\
\hline 16 & $0 \mathrm{ml} / 1 \mathrm{H}$ dan 15 ton $/ \mathrm{ha} \mathrm{T}(\mathrm{A} 1)$ & $18.33 \pm 0.33 \mathrm{ghi}$ & 32 & $10 \mathrm{ml} / 1 \mathrm{H}$ dan 0 ton $/ \mathrm{ha} \mathrm{T}(\mathrm{A} 2)$ & $12.66 \pm 0.33 \mathrm{n}$ \\
\hline
\end{tabular}

Keterangan: Angka-angka pada kolom yang diikuti huruf kecil yang tidak sama menunjukkan berbeda nyata menurut uji lanjut DMRT $\mathrm{p}<0.05$. Tanda \pm adalah nilai standard error. A1: Mentimun F1, A2 : Mentimun 


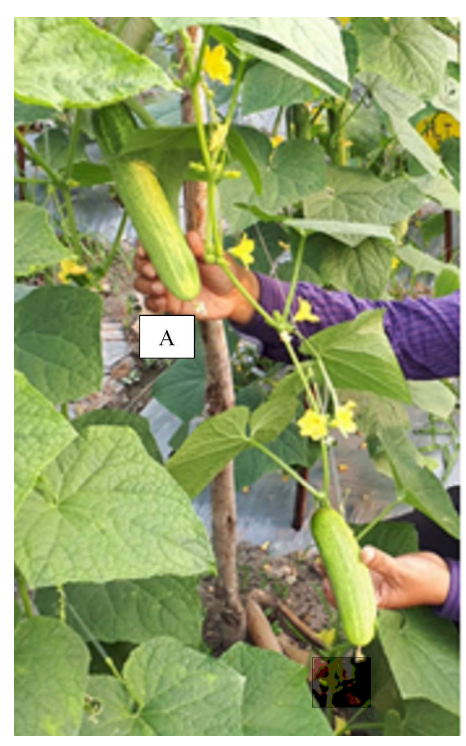

Gambar 4.2 Pertumbuhan generatif keadaan buah pertama, (A) mentimun mercy F1 dan (B) mercy mutan

Respon mentimun mercy mutan yang rendah terhadap kombinasi POC Herbafarm dan Kompos TKKS dalam merangsang pertumbuhan generatif panjang buah. Hal ini disebabkan karena faktor perubahan genetik yang terjadi dalam selnya dan bukan karena ketersediaan unsur hara dalam tanah. Hasil pengamatan ini didukung penelitian sebelumnya oleh Haryanti dkk.(2009), yang menyatakan pemberian klkisin telah menghambat pertumbuhan tanaman. Penyebab lain rendahnya hasil panjang buah bisa disebabkan oleh asal benih waktu perlakuan mutasi dengan kolkisin konsentrasinya tinggi yang menyebabkan kerusakan struktur kromosom (Sartika dan Basuki, 2017). Terdapat bagian gen yang tidak hilang atau fungsi ekpresinya gennya tidak aktif. Penelitian Sirojuddin dkk. (2017), juga terjadi penghambatan pertumbuhan tanaman zaitun yang diberi perlakuan kolkisin, sedangkan yang tanaman zaitun kontrol pertumbuhannya lebih cepat.

\section{Kemanisan buah (brix)}

Interaksi perlakuan POC Herbafarm dan pupuk kompos TKKS pada tanaman mentimun menunjukkan berbeda nyata pada parameter pengamatan kemanisan buah seperti dapat dilihat

Tabel 4.6 Kemanisan buah (brix) per tanaman mentimun varietas mercy F1 (H_T_A1) dan mutan mercy (H_T_A2) dengan perlakuan POC herbafarm pupuk kompos TKKS

\begin{tabular}{|c|c|c|c|c|c|}
\hline No & $\begin{array}{c}\text { Kombinasi (H) dan Kompos } \\
\text { TKKS (T) }\end{array}$ & Rerata & No & $\begin{array}{c}\text { Kombinasi Herbafarm }(\mathrm{H}) \\
\text { dan Kompos TKKS }(\mathrm{T})\end{array}$ & Rerata \\
\hline 1 & $15 \mathrm{ml} / 1 \mathrm{H}$ dan 20 ton/ha $\mathrm{T}$ (A1) & $4.86 \pm 0.13 \mathrm{a}$ & 17 & $15 \mathrm{ml} / 1 \mathrm{H}$ dan 0 ton/ha $\mathrm{T}$ (A2) & $3.60 \pm 0.33$ bcdef \\
\hline 2 & $10 \mathrm{ml} / 1 \mathrm{H}$ dan 25 ton $/ \mathrm{ha} \mathrm{T}(\mathrm{A} 2)$ & $4.66 \pm 0.30 \mathrm{ab}$ & 18 & $15 \mathrm{ml} / 1 \mathrm{H}$ dan 20 ton $/ \mathrm{ha} \mathrm{T}$ (A2) & $3.33 \pm 0.33 \mathrm{cdefg}$ \\
\hline 3 & $15 \mathrm{ml} / 1 \mathrm{H}$ dan 25 ton/ha $\mathrm{T}$ (A1) & $4.66 \pm 0.30 \mathrm{ab}$ & 19 & $5 \mathrm{ml} / 1 \mathrm{H}$ dan 25 ton/ha $\mathrm{T}$ (A2) & $3.33 \pm 0.33$ cdefg \\
\hline 4 & $15 \mathrm{ml} / 1 \mathrm{H}$ dan 0 ton/ha $\mathrm{T}$ (A1) & $4.66 \pm 0.48 \mathrm{ab}$ & 20 & $0 \mathrm{ml} / 1 \mathrm{H}$ dan 15 ton/ha $\mathrm{T}$ (A1) & $3.33 \pm 0.17$ cdefg \\
\hline 5 & $15 \mathrm{ml} / 1 \mathrm{H}$ dan 15 ton/ha $\mathrm{T}$ (A1) & $4.33 \pm 0.33 \mathrm{abc}$ & 21 & $10 \mathrm{ml} / 1 \mathrm{H}$ dan 25 ton/ha $\mathrm{T}$ (A1) & $3.33 \pm 0.33$ cdefg \\
\hline 6 & $15 \mathrm{ml} / 1 \mathrm{H}$ dan 25 ton/ha $\mathrm{T}$ (A2) & $4.26 \pm 0.17 \mathrm{abcd}$ & 22 & $10 \mathrm{ml} / 1 \mathrm{H}$ dan 0 ton/ha $\mathrm{T}(\mathrm{A} 1)$ & $3.26 \pm 0.26$ cdefg \\
\hline 7 & $10 \mathrm{ml} / 1 \mathrm{H}$ dan 25 ton/ha $\mathrm{T}$ (A1) & $4.20 \pm 0.2 \mathrm{abcd}$ & 23 & $0 \mathrm{ml} / 1 \mathrm{H}$ dan 0 ton/ha $\mathrm{T}$ (A1) & $3.20 \pm 0.2$ defg \\
\hline 8 & $10 \mathrm{ml} / 1 \mathrm{H}$ dan 15 ton/ha $\mathrm{T}$ (A2) & $4.00 \pm 0.00$ abcde & 24 & $5 \mathrm{ml} / 1 \mathrm{H}$ dan 0 ton $/ \mathrm{ha} \mathrm{T}$ (A1) & $3.20 \pm 0.2 \mathrm{defg}$ \\
\hline 9 & $10 \mathrm{ml} / 1 \mathrm{H}$ dan 20 ton/ha $\mathrm{T}(\mathrm{A} 1)$ & $3.93 \pm 0.52$ abcdef & 25 & $0 \mathrm{ml} / 1 \mathrm{H}$ dan 20 ton/ha $\mathrm{T}$ (A2) & $3.06 \pm 0.06$ efg \\
\hline 10 & $0 \mathrm{ml} / 1 \mathrm{H}$ dan 20 ton/ha $\mathrm{T}$ (A1) & $3.86 \pm 0.46$ abcdef & 26 & $5 \mathrm{ml} / 1 \mathrm{H}$ dan 20 ton/ha $\mathrm{T}$ (A2) & $3.00 \pm 0.00$ efg \\
\hline 11 & $5 \mathrm{ml} / 1 \mathrm{H}$ dan 20 ton/ha $\mathrm{T}(\mathrm{A} 1)$ & $3.86 \pm 0.13$ abcdef & 27 & $0 \mathrm{ml} / 1 \mathrm{H}$ dan 15 ton/ha $\mathrm{T}(\mathrm{A} 2)$ & $3.00 \pm 0.00$ efg \\
\hline 12 & $10 \mathrm{ml} / 1 \mathrm{H}$ dan 20 ton/ha $\mathrm{T}(\mathrm{A} 2)$ & $3.66 \pm 0.33$ bcdef & 28 & $5 \mathrm{ml} / 1 \mathrm{H}$ dan 15 ton/ha $\mathrm{T}(\mathrm{A} 2)$ & $3.00 \pm 0.00 \mathrm{efg}$ \\
\hline 13 & $15 \mathrm{ml} / 1 \mathrm{H}$ dan 15 ton/ha $\mathrm{T}(\mathrm{A} 2)$ & $3.66 \pm 0.33$ bcdef & 29 & $0 \mathrm{ml} / 1 \mathrm{H}$ dan 0 ton $/ \mathrm{ha} \mathrm{T}$ (A2) & $2.88 \pm 0.13 \mathrm{fg}$ \\
\hline 14 & $10 \mathrm{ml} / 1 \mathrm{H}$ dan 15 ton/ha $\mathrm{T}$ (A1) & $3.66 \pm 0.33$ bcdef & 30 & $5 \mathrm{ml} / 1 \mathrm{H}$ dan 15 ton/ha $\mathrm{T}(\mathrm{A} 1)$ & $2.88 \pm 0.13 \mathrm{fg}$ \\
\hline 15 & $0 \mathrm{ml} / 1 \mathrm{H}$ dan 25 ton/ha $\mathrm{T}$ (A1) & $3.66 \pm 0.33 \mathrm{bcdef}$ & 31 & $0 \mathrm{ml} / 1 \mathrm{H}$ dan 25 ton/ha $\mathrm{T}$ (A2) & $2.50 \pm 0.50 \mathrm{~g}$ \\
\hline 16 & $5 \mathrm{ml} / 1 \mathrm{H}$ dan 0 ton/ha $\mathrm{T}(\mathrm{A} 2)$ & $3.60 \pm 0.30$ bcdef & 32 & $10 \mathrm{ml} / 1 \mathrm{H}$ dan 0 ton/ha $\mathrm{T}(\mathrm{A} 2)$ & $2.33 \pm 0.33 \mathrm{~g}$ \\
\hline
\end{tabular}

Keterangan: Angka-angka pada kolom yang diikuti huruf kecil yang tidak sama menunjukkan berbeda nyata menurut uji lanjut DMRT $\mathrm{p}<0.05$. Tanda \pm adalah nilai standard error. A1: Mentimun F1, A2 : Mentimun 
pada Tabel 4.6. Berdasarkan Tabel 4.6 kombinasi perlakuan $15 \mathrm{ml} / 1$ POC herbafarm dan 20 ton/ha kompos TKKS menghasilkan 4.86 brix pada varietas F1 mercy. Konsentrasi 15 ml/1 POC herbafarm dan 25 ton/ha kompos TKKS menghasilkan 4.66 brix pada mercy mutan yang merupakan angka tertinggi dari keseluruhan interaksi perlakuan. Pengaruh interaksi perlakuan konsentrasi POC herbafarm dan kompos TKKS berbeda nyata. Tinggi rendahnya konsentrasi dan dosis sedikit mempengaruhi kualitas brix. Oleh karena itu tingkat brix tidak dipengaruhi sepenuhnya oleh kandungan unsur hara yang ada di dalam tanah. Faktor lingkungan berkemungkinan dapat mempengaruhi seperti intensitas cahaya dan lama penyinaran sinar matahari terhadap tanaman. Perlakuan dosis herbafarm maksimum $6 \mathrm{cc} / 1$ air dapat meningkatkan akumulasi bio-protectant dan meningkatkan sistem imunitas yang menyebabkan tanaman mengoptimalkan faktor lingkungan seperti cahaya matahari, suhu, kelempan dan airuntuk memacu pembentukan buah yang lebih banyak. Penelitian Setyoko dkk. (2012), menunjukkan bahwa pemberian pupuk POC herbafarm $6 \mathrm{cc} / 1$ air memberikan pengaruh nyata terhadap peningkatan jumlah buah. Pengaruh POC herbafarm positif terhadap reaksi-reaksi penguraian dalam tubuh tanaman sehingga terjadi peningkatan kemanisan buah. Penelitian sebelumnya oleh Rahmansyah dkk. (2012), menunjukkan herbafarm $6 \mathrm{cc} / 1$ air memberikan pengaruh terbaik terhadap fase generatif. Hasil penelitian Permanasari dan Annisava (2015), menunjukkan peningkatan hasil mentimun lebih tinggi pada kompos TKKS dibandingkan perlakukan lain.

\section{KESIMPULAN}

Hasil pengamatan tinggi tanaman pada mentimun mercy F1 pada perlakuan kombinasi $10 \mathrm{ml} /$ 1 POC herbafarm dan 20 ton/ha kompos TKKS membuktikan konsentrasi POC herbafarm dan dosis TKKS yang terbaik pada mentimun mercy F1. Selain itu pada pengamatan umur berbunga juga merupakan perlakuan yang terbaik kombinasi $15 \mathrm{ml} / 1$ POC herbafarm dan 15 ton/ha kompos TKKS.

Jumlah buah tertinggi diperoleh dari perlakuan $15 \mathrm{ml} / 1$ POC herbafarm dan 25 ton/ha kompos TKKS untuk mercy mutan. Perlakuan $15 \mathrm{ml} / 1$ POC herbafarm dan 25 ton/ha kompos TKKS dan juga 10 ml/1 POC herbafarm dan 20 ton/ha kompos TKKS membukti menghasilkan berat dan panjang buah tertinggi pada mentimun mercy F1. Hasil pengamatan brix konsentrasi POC herbafarm dan dosis TKKS tertinggi mempengaruhi untuk kedua jenis mentimun.

\section{UCAPAN TERIMA KASIH}

Kami mengucakan terima kasih kepada Rektor Universitas Islam Riau, melalui Ketua lembaga Penelitian dan Pengabdian Masyarakat (LPPM) UIR yang telah mendanai penelitian ini dengan Kontrak Penelitian Tahun Anggaran 2019 No: 620/Kontrak/ LPPM-UIR/2019. 


\section{DAFTAR PUSTAKA}

Abdurrazak, Hatta, M. dan Marliah, A. 2013. Pertumbuhan dan hasil tanaman mentimun (Cucumis sativus) akibat perbedaan jarak tanam dan jumlah benih per lubang tanam. Jurnal Agrista Vol. 17 No. 2 Agro Indonesia. Jakarta. 69 hal.

Andrie, K.L. , Napitupulu, M. dan Jannah, N. 2015. Respon tanaman mentimun (cucumis sativus 1.) terhadap jenis poc dan konsentrasi yang berbeda. Jurnal Agrifor, 14 (1)

Anjarwati, D. 2014. Pengaruh Pemberian Pupuk NPK Organik dan Herbafarm Cair terhadap Pertumbuhan dan Hasil Tanaman Terung (Solanum melongena L). Skripsi. Fakultas Pertanian Universitas Islam Riau. Pekanbaru.

Anonimus. 2011. Kandungan Unsur hara dan Manfaat Pupuk Bio-Organik Herbafarm. PT. Sido Muncul. Tbk. Jawa Timur.

Arif, I. 2013. Pemanfaatan pupuk kandang ayam dan aplikasi herbafarm ayam terhadap pertumbuhan dan hasil tanaman kangkung (Ipomoea reptans L.) Skripsi Fakultas Pertanian UNA, Kisaran.

Badan Pusat Statistik Provinsi Riau. 2017. Riau Dalam Angka 2015. Pekanbaru. Riau.

Bariyanto, Nelvia dan Wardati. 2015. Pengaruh pemberian kompos tanda kosong kelapa sawit (TKKS) pada pertumbuhan bibit kelapa sawit (Elaeis guineensis Jacq) di main-nursery pada medium subsoil ultisol. Jom Faperta, 2 (1)

Dinarti, D., Yudiwanti dan Rahayuningsih, S. 2006. Pengaruh Kolkisin Terhadap Kevarianan Fenotipe dan Jumlah Kromosom Jahe Emprit (Zingiber officinale L). asal In Vitro, p. 88-91.

Evi, N.A., Respatijarti dan Arifin, N.S. 2016. Pengaruh pemberian kolkisin terhadap penampilan fenotip galur inbrida jagung pakan (Zea mays 1.) pada fase pertumbuhan vegetatif. Jurnal Produksi Tanaman Vol. 4 No. 5.
Firmansyah, M.A. 2010. Teknik pembuatan kompos. Pelatihan plasma petani kelapa sawit di Kabupaten Sukamara. Peneliti di Balai Pengkajian Teknologi Pertanian (BPTP) Kalimantan Tengah.

Haryanti. S, Hastuti, R.B., Setiari, N. dan Banowo, A. 2009. Pengaruh kolkisin terhadap pertumbuhan, ukuran sel metafase dan kandungan protein biji tanaman kacang hijau (Vigna radiata (L) Wilczek). Jurnal Penelitian Sains \& Teknologi, Vol. 10, No. 2: 112 - 120.

Nasri, M. 2013. Pemberian Pupuk Kascing dan Herbafarm Pada Tanaman Pare (Momordica charantia L). Skripsi Fakultas Pertanian Universitas Islam Riau. Pekanbaru.

Permanasari, I. dan Annisava, A.R. 2015. Upaya peningkatan hasil mentimun secara organik dengan sistem Tasalampot. Jurnal Agroteknologi, Vol. 6 No. 1: 17 - 24.

Purnamayani, R., Purnama, H., Syafri, E. 2019. Aplikasi Kompos Tandan Kosong Kelapa Sawit pada Tanaman Timun (Cucumis sativa) di Kabupaten Merangin, Jambi Balai Pengkajian Teknologi Pertanian (BPTP) Jambi. Diperoleh dari http://jambi.litbang.pertanian. go.id/ind/images/ PDF/rimal.pdf diakses 18 Juni 2019.

Pusat Penelitian Kelapa Sawit. 2000. Budidaya Kelapa Sawit. Modul M: 100-203. Medan.

Rachmansyah, Bambang, K. Y dan Yusni A. R. 2012. Aplikasi Pemberian Berbagai Jenis dan Dosis pupuk Bio Organik Pada Tanaman Pare. Jurnal Floratek 24 (2) : 17-24. Universitas Syah Kuala. Diperoleh dari http://www.jurnal. unsyiah.ac.id/floratek/article/view.

Rahayu, E.M.D, Sukma, D, Syukur, M,Aziz, S.A. dan Irawati. 2015. Induksi poliploidi menggunakan kolkisin secara in vivo pada bibit anggrek bulan (Phalaenopsis amabilis (L.) Blume). Buletin Kebun Raya Vol. 18 No. 1,. hal 41-48. 
Rahman, A.F., Nandariyah dan Parjanto. 2017. Keanekaragaman pertumbuhan dan hasil tanaman oyong (Luffa acutangula 1.) pada berbagai konsentrasi kolkhisin. AgrotechResJ. $1(1): 1-6$.

Ramasadewo, D. 2015. Aplikasi kompos serbuk kayu dan pupuk herbafarm terhadap pertumbuhan dan produksi tanaman cabe merah (Capsicum annum L.) Faperta UIR.

Sartika, T. V. dan Basuki, N. 2017. Pengaruh konsentrasi kolkisin terhadap perkitan putative mutan semangka (Citrullus lanatus). Jurnal Produksi Tanaman Vol. 5. No 10: 1669-1677.

Sarwono, E. 2008. Pemanfaatan Janjang Kosong Sebagai Substansi Pupuk Tanaman Kelapa Sawit Jurnal APLIKA.8(1):33-45.

Setyoko,Y. Sukaya dan Pardono. 2012. Pengaruh Macam dan Dosis Pupuk Organik terhadap Pertumbuhan dan Hasil Tanaman Pare (Momordica Charantia L). Jurnal Sains dan Teknologi Indonesia, 3 (5) : 55-63
Sirojuddin, Rahayu, T., Laili, S. 2017. Pengaruh Pemberian Berbagai Konsentrasi Kolkisin dan Lama Perendaman terhadap Respon Fenotipik Zaitun (Olea europaea). Jurnal Ilmiah Biosaintropis (Bioscience-Tropic),2(2):36-41.

Sudiakarta, D.A., 2006. Pupuk organik dan pupuk hayati. Bandung. Badan Penelitian dan Pengembangan Pertanian.

Suriadikarta, Didi A., Simanungkalit, R.D.M. 2013. Pupuk organik dan pupuk hayati. Jawa Barat: Balai Besar Penelitian dan Pengembangan Sumberdaya Lahan Pertanian. Hal 2. ISBN 978-979- 9474-57-5.

Zulaikhah, S. 2012. Pengaruh Pemberian Pupuk Herbafarm dan NPK Organi Terhadap Pertumbuhan dan Produksi Tanaman Pare (Montordica Charantia L). Jurnal Hortikultura, 21 (1) : 1-8

Zulkarnaeni. 2011. Dasar-Dasar Hortikultura. Bumi Aksara. Jakarta. 